\title{
Evaluation of post-operative pain and stress in dogs after elective ovariohysterectomy under hospitalization
}

\author{
Avaliação da dor e estresse pós-operatórios em cadelas mantidas em \\ ambiente hospitalar submetidas à ovariohisterectomia eletiva
}

\author{
Nathália Gonçalves de Santana ${ }^{1}$ (D); Christina Malm ${ }^{1}$ (D); Mariana Zanini Maia ${ }^{1}$ (D); Tábata Megda ${ }^{1}$ (D); \\ Suzane Lilian Beier ${ }^{1}$ (D); Leonardo Dias Mamão ${ }^{1}$ (D); Thaíssa Castro Franco ${ }^{1}$ (D)
}

${ }^{1}$ Universidade Federal de Minas Gerais, Escola de Veterinária, Departamento de Clínica e Cirurgia Veterinárias, Belo Horizonte - MG, Brazil

\begin{abstract}
Surgical procedures in pet animals are usually associated with some degree of stress and pain. Hospitalization is one stress-triggering factor. The present study aimed to evaluate the degree of stress and pain during hospitalization of female dogs submitted to elective ovariohysterectomy $(\mathrm{OVH})$ and to investigate the influence of hospitalization on the stress of these animals. Fifteen young adult crossbreed female dogs were divided into two groups: eight animals without surgery (Group 1 - control) and seven animals submitted to surgery (Group 2 - OVH). Pain and stress were evaluated. Visual analogue scale (VAS), simple descriptive pain scale (SDS) and modified Glasgow pain scale (MGPS) were used. Serum cortisol $(\mu \mathrm{g} / \mathrm{dL})$ and glucose $(\mathrm{mg} / \mathrm{dl})$ were also measured. No statistical difference was observed for cortisol $(\mu \mathrm{g} / \mathrm{dL})$ between the two groups. Despite the absence of statistical difference between groups and times, mean serum cortisol $(\mu \mathrm{g} / \mathrm{dL})$ values exceeded the normal values for the canine species at various times evaluated. Hyperglycemia was only observed at T4 in the OVH group. It was concluded that the hospitalization of animals was more relevant in the establishment of stress than the surgical procedure and associated pain. The influence of stress was a relevant factor in the results of assessments carried out using the MGPS.
\end{abstract}

Keywords: Dog. Stress. Pain. Ovariohysterectomy. Hospitalization.

\section{RESUMO}

Os procedimentos cirúrgicos em animais de companhia são geralmente associados a algum grau de dor e estresse e a hospitalização é um dos fatores que predispõem ao estresse. O presente estudo teve o objetivo de avaliar o grau de estresse e dor durante a internação de cadelas submetidas à ovariohisterectomia eletiva $(\mathrm{OVH})$ e investigar a influência da hospitalização sobre o estresse nestes animais. Quinze cadelas adultas jovens e mestiças foram divididas em dois grupos: oito animais não submetidos à cirurgia (Grupo 1 - controle) e sete animais submetidos à OVH (Grupo 2 - OVH). Dor e estresse foram avaliados. Foram utilizadas a escala visual analógica (EVA), escala descritiva simples (EDS) e escala de dor de Glasgow modificada (EDGM). A glicose $(\mathrm{mg} / \mathrm{dL})$ e o cortisol $(\mu \mathrm{g} / \mathrm{dL})$ séricos foram mensurados. Não houve diferença estatística do cortisol $(\mu \mathrm{g} / \mathrm{dL})$ entre os grupos. Entretanto, os valores médios de cortisol $(\mu \mathrm{g} / \mathrm{dL})$ excederam àqueles considerados normais para a espécie canina em vários períodos avaliados. A hiperglicemia foi observada em T4 no grupo OVH. Concluiu-se que a hospitalização dos animais foi mais relevante na ocorrência do estresse do que o procedimento cirúrgico e a dor associada a ele. Desta forma, a influência do estresse foi um fator relevante nos resultados das avaliações realizadas com a escala de dor de Glasgow modificada.

Palavras-chave: Cão. Estresse. Dor. Ovariohisterectomia. Hospitalização. 
Correspondence to:

Mariana Zanini Maia

Universidade Federal de Minas Gerais, Escola de Veterinária,

Departamento de Clínica e Cirurgia Veterinárias

Av. Antônio Carlos, 6627, Pampulha, CP 567

CEP: 30123-970, Belo Horizonte - MG, Brazil

e-mail: mzaninimaia@hotmail.com

Received: October 04, 2019

Approved: July 29, 2020

How to cite: Santana NG, Malm C, Maia MZ, Megda T, Beier SL, Mamão LD, Franco TC. Evaluation of post-operative pain and stress in dogs after elective ovariohysterectomy under hospitalization. Braz J Vet Res Anim Sci. 2020;57(3):e162908. https://doi.org/10.11606/ issn.1678-4456.bjvras.2020.162908

\section{Introduction}

Surgical procedures in companion animals are usually associated with some degree of stress and pain, even with adequate post-operative analgesia. Minimizing pain and stress is a common goal of veterinary surgeons (Michelsen et al., 2012). Hospitalization of these animals, often necessary for their full recovery, is another stress-triggering factor due to confinement, loss of familiarity with the environment, social isolation, lack of predictability of events and absence of an animal's familiar caregiver (Hekman et al., 2012; Lefman \& Prittie, 2019; Väisänen et al., 2005).

Physiological stress is not harmful to the body, being an adaptive mechanism that prepares the individual to respond to environmental stimuli (Hekman et al., 2014). However, intense and chronic stress is harmful to animals, and various conditions such as fear, frustration, overstimulation, surgical procedures, pain and hospitalization can compromise the animal's well-being (Broom, 1991; Kitchen et al., 1987; Koknaroglu \& Akunal, 2013; Lloyd, 2017; Möstl \& Palme, 2002). Several hormones (adrenocorticotropic, glucocorticoids, catecholamines, and prolactin, among others) are involved in the stress condition, and adrenal glands play an important role in this mechanism, related with hypothalamic-pituitaryadrenocortical and sympathetic-adrenal-medullary axes (Hekman et al., 2014; Möstl \& Palme, 2002; Willen at al., 2017). Cortisol $(\mu \mathrm{g} / \mathrm{dL})$ is the main indicator of stress (Broom, 1991; Hekman et al., 2012; Möstl \& Palme, 2002; Zanella et al., 2009), and another important indicator of metabolic stress is serum glucose $(\mathrm{mg} / \mathrm{dL})$, which tends to be increased after surgical trauma (Freeman et al., 2010). Physiological parameters such as body temperature, blood pressure and heart and respiratory rates are also reported as indicators of stress and pain in dogs (Freeman et al., 2010; Hekman et al., 2014; Hellyer \& Gaynor, 1998; Hellyer et al., 2007; Lefman \& Prittie, 2019; Srithunyarat et al., 2016; Väisänen et al., 2005; Zanella et al., 2009).

Furthermore, behavioral signs can be used to assess the presence or absence of stress in animals (Väisänen et al., 2005). Vocalization, change in feeding habits, facial expression, interactive behavior and atypical body postures can reveal signs of pain, discomfort, disease or suffering (Beerda et al., 1997; Hellyer \& Gaynor, 1998; Lefman \& Prittie, 2019).

Pain is related directly to emotional issues, such as fear and anxiety. However, these concepts are subjective (Lefman \& Prittie, 2019), and to distinguish an animal's pain from a stress response becomes challenging (Matičić et al., 2010).

This study aims to investigate pain and stress in female dogs submitted to ovariohysterectomy and control group, also evaluating the influence of hospitalization on animals.

\section{Material and Methods}

This study was approved by the Ethics Committee on the Use of Animals of the Federal University of Minas Gerais (UFMG) on March 30, 2015, under protocol 66/2015. Fifteen young adult crossbreed female dogs, weighing between $7 \mathrm{~kg}$ and $20 \mathrm{~kg}$, participated in this study, randomly distributed in 2 groups. Eight animals were hospitalized without surgery (Group 1 - control) and seven animals were hospitalized and submitted to elective ovariohysterectomy (Group 2 - OVH). All animals underwent the same conditions of hospitalization.

All female dogs came from a rescued animal shelter and were referred for elective OVH for population control purposes. The animals' guardians signed the "Informed Consent Form" attesting to the knowledge of the terms of the study and authorizing the participation of the animals.

The animals were previously subjected to a full clinical examination, surgical risk tests (blood count, urea and creatinine levels, and glycemia (mg/dL)) and abdominal ultrasonography to exclude diseases that could interfere in this study. All animals, in both groups, were admitted at veterinary hospital $24 \mathrm{~h}$ before the beginning of analysis to provide a period of adaptation to the hospital environment and minimize stress and standardize assessments related to hospitalization (Hellyer et al., 2007).

All animals were accommodated in individual kennels and remained hospitalized for $48 \mathrm{~h}$ after sedation (G1) or after surgery (G2) to perform evaluations of this study. All dogs were subjected to $12 \mathrm{~h}$ of food fasting and $4 \mathrm{~h}$ of water fasting before pre-anesthetic medication. All animals in both groups were given pre-anesthetic medication 
with methadone hydrochloride (Mytedon ${ }^{\circledR}$, Cristália, São Paulo, São Paulo, Brazil) (0.5 mg Kg/IM). A venous access was then punctured in the cephalic vein, and a ventral abdominal trichotomy for OVH was carried out. Group 2 animals underwent intravenous (IV) anesthetic induction using $1 \%$ propofol (Fresofol $1 \%{ }^{\circledR}$, Fresenius Kabi Brasil Ltda, Campinas, São Paulo, Brazil) (5 mg/kg/IV) and fentanyl (Fentanest ${ }^{\circledR}$, Cristália, São Paulo, São Paulo, Brazil) $(5 \mu \mathrm{g} / \mathrm{kg} / \mathrm{IV})$. After orotracheal intubation, anesthesia was maintained using isoflurane (Isothane ${ }^{\circledR} 100 \mathrm{ml}$, Baxter Hospitalar Ltda., Santo Amaro, São Paulo, Brazil) in an inhalation anesthetic device in a semi-closed circular system (1.5 v\%). During anesthesia, the animals were monitored every $5 \mathrm{~min}$ for heart and respiratory rate, body temperature, non-invasive blood pressure with Doppler, pulse oximetry and electrocardiography. The animals were kept at a body temperature between 35.5 and $39.2^{\circ} \mathrm{C}$ with the aid of thermal mattress, arterial systolic pressure above $100 \mathrm{mmHg}$, heart rate between 80 and $120 \mathrm{bpm}$ and respiratory rate between 8 and $12 \mathrm{mpm}$. During anesthesia, changes in fluid therapy infusion rate and inhalational anesthetic concentration were performed, when necessary, to maintain the animal with the physiological parameters mentioned above.

Antisepsis of the surgical field was performed according to the principles described by Fossum (2008). Group 2 animals were submitted to the OVH technique (Stone, 2007) and surgical time was defined from the moment of skin incision to skin suturing, with average time of 20 minutes.

During hospitalization, the animals were kept in individual kennels at UFMG Veterinary Hospital for $48 \mathrm{~h}$ and received commercial dry dog food twice a day and water ad libitum. To mimic all stress conditions inherent to hospitalization, both groups had a venous access (IV and extender equipment), surgical clothing and Elizabethan collar maintained during the 48-h hospitalization.

Group 2 animals $(\mathrm{OVH})$ received two doses of cephalothin sodium (Cefalotina Sódica, Antibióticos do Brasil, Cosmópolis, São Paulo, Brazil) (30 mg/Kg/IV), one dose immediately before surgery, and the other dose $2 \mathrm{~h}$ later. Post-operative analgesia consisted of local blockage of the surgical wound with bupivacaine without vasoconstrictor (Neocaína ${ }^{\circledR}$, Cristália, São Paulo, São Paulo, Brazil) (3 mg/ $\mathrm{kg}$ ), tramadol hydrochloride (Cloridrato de Tramadol, União Química Farmacêutica Nacional S/A, Jabaquara, São Paulo, Brazil) (5 mg/Kg/SC) and scopolamine/dipyrone (Buscofin $^{\circledR}$, União Química Farmacêutica Nacional S/A, Jabaquara, São Paulo, Brazil) $(25 \mathrm{mg} / \mathrm{Kg} / \mathrm{IV})$, every $8 \mathrm{~h}$, during the following $48 \mathrm{~h}$.
To estimate stress and pain levels, behavioral assessment and blood sample collection (cortisol - $\mu \mathrm{g} / \mathrm{dL}$ - and glucose- $\mathrm{mg} / \mathrm{dL}$ ) were carried out at seven time points: T0 immediately before the surgery (Group 2), and the equivalent time (Group 1); T4 - $4 \mathrm{~h}$ after surgery (Group 2) and $4 \mathrm{~h}$ after sedation (Group 1); T8 - 8 h after surgery (Group 2) and $8 \mathrm{~h}$ after sedation (Group 1); T12 - $12 \mathrm{~h}$ after surgery (Group 2) and $12 \mathrm{~h}$ after sedation (Group 1); T24 - $24 \mathrm{~h}$ after surgery (Group 2) and $24 \mathrm{~h}$ after sedation (Group 1); T36 - $36 \mathrm{~h}$ after surgery (Group 2 ) and $36 \mathrm{~h}$ after sedation (Group 1); T48 - $48 \mathrm{~h}$ after surgery (Group 2) and $48 \mathrm{~h}$ after sedation (Group 1).

In both groups, the first assessment (T0) invariably occurred between 7:00 a.m. 9:00 a.m.

\section{Assessment of behavior, pain, sedation, and stress}

Three scales were used to assess post-operative pain. The Modified Glasgow Pain Scale (MGPS) was used and behavioral assessments were based on posture, vocalization, attention to the surgical wound, mobility, response to surgical wound manipulation, behavior and comfort of the animal. The total possible score ranges from 0 to 10 , where 0 represents "complete absence of pain," and 10 represents "maximum possible pain." (Morton et al., 2005.) Although it is a pain rating scale, the MGPS includes behavioral parameters directly related to stress, such as vocalization, locomotion, atypical body postures, changes in behavior and facial expressions (Hellyer \& Gaynor, 1998).

Beyond the MGPS, the visual analogue scale (VAS) and simple descriptive scale (SDS) were applied to assess pain. Sedation level was assessed by VAS and SDS. The VAS is a 10- $\mathrm{cm}$ line in which the extreme left mark (0) indicates an alert or pain-free animal and the extreme right mark (10) indicates the highest level of sedation or maximum possible pain. Analgesic rescue was performed on animals with a score $\geq 5$ in the VAS and/or $>2$ in the SDS. All evaluations were carried out by a single experienced appraiser, as described by Moll et al.(2011).

\section{Serum cortisol and glucose dosage}

At all the time points listed above, blood samples were collected using jugular venipuncture. Immediately after collection, the samples were centrifuged, the serum frozen at $-20^{\circ} \mathrm{C}$ and analyzed by radioimmunoassay method for cortisol $(\mu \mathrm{g} / \mathrm{dL})$ measurement and biochemistry analyzer for glucose $(\mathrm{mg} / \mathrm{dL})$ measurement. Interval references of cortisol and glucose were 1.80-4.00 $\mu \mathrm{g} / \mathrm{dL}$ and $.70-110 \mathrm{mg} / \mathrm{dL}$, respectively (Jericó, 2015; Nelson et al., 2004). 


\section{Statistical analysis}

In this study, a completely randomized design with split plots was used, in which the absence or performance of the surgical procedure constituted the plots.

The assessment times represented the subplots and each animal, an experimental unit or repetition. Differences with $\mathrm{p}<0.05$ were considered significant. Responses were subjected to different tests: analysis of variance and the Student-Newman-Keuls (SNK) test, analysis of variance and the SNK test, Kruskal-Wallis test (KW) and Pearson correlation.

\section{Results}

\section{Stress, pain, and sedation scale}

Median values and standard deviations for pain analogue visual scale (VAS) scores are presented in Table 1. In the comparison between groups, there was a statistical difference in times $\mathrm{T} 4$ to $\mathrm{T} 48$, with higher means in group $2(\mathrm{OVH})$ for these times. In group 1 (control), over the evaluated times, there was no statistical difference. In group $2(\mathrm{OVH})$, over the evaluated times, there was a difference in $\mathrm{T} 4$ in relation to T0 (preoperative) and T48. At T4, the averages were the highest.
The values of medians and standard deviations for the simple descriptive pain (SDS) scores are shown in Table 2. In the comparison between groups, there was a statistical difference in times $\mathrm{T} 4$ to $\mathrm{T} 24$, with higher means in group $2(\mathrm{OVH})$ for these times. In group 1 (control), over the evaluated times, there was no statistical difference. In group $2(\mathrm{OVH})$, over time, there was a difference in $\mathrm{T} 4$, T8, T12 and in relation to T0 (pre-surgery), T36 and T48.

The median values and standard deviations for sedation visual analog scale (VAS) scores for sedation are shown in Table 3. In the comparison between groups, there was no statistically significant difference. In group 1 (control), over the evaluated times, there was a difference of $\mathrm{T} 4$ in relation to all other evaluated times. In group $2(\mathrm{OVH})$, over time, there was a difference of $\mathrm{T} 4$ in relation to the other times, except T8. T8 difference was also observed in relation to T0 (preoperative), T24, T36 and T48.

The values of medians and standard deviations for the simple descriptive scale (SDS) scores for sedation are shown in Table 4. In the comparison between groups, there was no statistically significant difference. In group 1 (control), over the evaluated times, there was a difference of $\mathrm{T} 4$ ( $4 \mathrm{~h}$ after sedation) in relation to the other evaluated times.

Table 1 - Medians and standard deviations of the visual analog scale (VAS) scores for pain at different times during the assessment in group 1 (control) and group 2 (OVH). Veterinary Hospital of the Federal University of Minas Gerais, June to October 2015

\begin{tabular}{lcccccccc}
\hline & $\mathbf{N}$ & T0 & T4 & T8 & T12 & T24 & T36 & T48 \\
\hline Group 1 (Control) & $\mathbf{8}$ & 0 & 0 & 0 & 0 & 0 & 0 & 0 \\
Group 2 (OVH) & & $\mathrm{AB} \mathrm{a}$ & $\mathrm{A} \mathrm{a}$ & $\mathrm{A} \mathrm{a}$ & $\mathrm{A} \mathrm{a}$ & $\mathrm{A} \mathrm{a}$ & $\mathrm{A} \mathrm{a}$ & $\mathrm{A} \mathrm{a}$ \\
& $\mathbf{7}$ & 0 & $3.8 \pm 0.95$ & $3.0 \pm 1.5$ & $1.9 \pm 1.78$ & $0.9 \pm 1.1$ & $0.6 \pm 0.35$ & $0.2 \pm 0.15$ \\
& & $\mathrm{AB} \mathrm{a}$ & $\mathrm{D}$ & $\mathrm{CD} \mathrm{b}$ & $\mathrm{CD} \mathrm{b}$ & $\mathrm{CD} \mathrm{b}$ & $\mathrm{CD} \mathrm{b}$ & $\mathrm{BC} \mathrm{b}$ \\
\hline
\end{tabular}

$\mathrm{N}=$ number of animals. Values followed by different capital letters are significantly different $(\mathrm{p}<0.05)$ among assessment times, and different lower case letters indicate that the values differ significantly between groups, according to the Kruskal-Wallis test.

Table 2 - Medians and standard deviations of the simple descriptive pain scale (SDS) scores at different times during the assessment in group 1 (control) and group 2 (OVH). Veterinary Hospital of the Federal University of Minas Gerais, June to October 2015

\begin{tabular}{lcccccccc}
\hline & N & T0 & T4 & T8 & T12 & T24 & T36 & T48 \\
\hline Group 1 (Control) & 8 & 1 & 1 & 1 & 1 & 1 & 1 & 1 \\
Group 2 (OVH) & 7 & $\mathrm{~A} \mathrm{a}$ & $\mathrm{A} \mathrm{a}$ & $\mathrm{A} \mathrm{a}$ & $\mathrm{A} \mathrm{a}$ & $\mathrm{A} \mathrm{a}$ & $\mathrm{A} \mathrm{a}$ & $\mathrm{A} \mathrm{a}$ \\
& & 1 & $3 \pm 0.49$ & $2 \pm 0.38$ & $2 \pm 0.38$ & $2 \pm 0$ & $1 \pm 0.49$ & $1 \pm 0.38$ \\
& & $\mathrm{~A} \mathrm{a}$ & $\mathrm{B} \mathrm{b}$ & $\mathrm{B} \mathrm{b}$ & $\mathrm{B} \mathrm{b}$ & $\mathrm{B} \mathrm{b}$ & $\mathrm{A} \mathrm{a}$ & $\mathrm{A} \mathrm{a}$ \\
\hline
\end{tabular}

$\mathrm{N}=$ number of animals. Values followed by different capital letters are significantly different $(\mathrm{p}<0.05)$ among assessment times, and different lower case letters indicate that the values differ significantly between groups, according to the Kruskal-Wallis test.

Table 3 - Medians and standard deviations of the visual analog scale (VAS) scores for sedation at different times during the assessment in group 1 (control) and group $2(\mathrm{OVH})$. Veterinary Hospital of the Federal University of Minas Gerais, June to October 2015

\begin{tabular}{lcccccccc}
\hline & N & T0 & T4 & T8 & T12 & T24 & T36 & T48 \\
\hline Group 1 (Control) & 8 & 0 & $1.6 \pm 1.14$ & $0 \pm 0.19$ & 0 & 0 & 0 & 0 \\
Group 2 (OVH) & 7 & $\mathrm{AB} \mathrm{a}$ & $\mathrm{C} \mathrm{a}$ & $\mathrm{AB} \mathrm{a}$ & $\mathrm{A} \mathrm{a}$ & $\mathrm{A} \mathrm{a}$ & $\mathrm{A} \mathrm{a}$ & $\mathrm{A} \mathrm{a}$ \\
& & 0 & $1.3 \pm 0.55$ & $0.6 \pm 0.42$ & $0 \pm 0.49$ & 0 & 0 & 0 \\
& & $\mathrm{~A} \mathrm{a}$ & $\mathrm{C} \mathrm{Ca}$ & $\mathrm{BC} \mathrm{a}$ & $\mathrm{AB} \mathrm{a}$ & $\mathrm{A} \mathrm{a}$ & $\mathrm{A} \mathrm{a}$ & $\mathrm{A} \mathrm{a}$ \\
\hline
\end{tabular}

$\mathrm{N}=$ number of animals. Values followed by different capital letters are significantly different $(\mathrm{p}<0.05)$ among assessment times, and different lower case letters indicate that the values differ significantly between groups, according to the Kruskal-Wallis test. 
In group $2(\mathrm{OVH})$, over time, there was a difference of $\mathrm{T} 4$ in relation to T0, T12, T24, T36 and T48.

The median values and standard deviations for the modified Glasgow pain scale (MGPS) scores are shown in Table 5.

In the comparison between groups, there was a statistical difference in times T36 and T48, with lower means in group $2(\mathrm{OVH})$ for these times. In group 1 (control), over the evaluated times, there was no statistical difference. In group $2(\mathrm{OVH}), \mathrm{T} 4$ differed significantly from $\mathrm{T} 8$, $\mathrm{T} 12, \mathrm{~T} 24, \mathrm{~T} 36$, and T48. At T4, the averages were the highest. Times T36 and T48 were statistically different from T0 (preoperative), T4 and T8. T36 and T48 showed differences in relation to T0 (preoperative), T4 and T8.

\section{Evaluation of serum cortisol and glucose}

Mean serum cortisol concentrations $(\mu \mathrm{g} / \mathrm{dL}-1)$ in both groups and at the times evaluated (T0-T48) are shown in Table 6. In the comparison between the groups, over the evaluated times, there was no statistical difference in serum cortisol levels $(\mu \mathrm{g} / \mathrm{dL})$. Despite the absence of statistical difference between groups and times, the mean serum cortisol values $(\mu \mathrm{g} / \mathrm{dL})$ exceeded the normal values for the canine species at various times evaluated. In group 1 (control), increased means for cortisol $(\mu \mathrm{g} / \mathrm{dL})$ were observed at all evaluation times.

In group $2(\mathrm{OVH})$, mean serum cortisol values $(\mu \mathrm{g} / \mathrm{dL})$ exceeded normal values at T0 (pre-surgery), T4 and T8.

The mean values obtained for blood glucose (mg/dL-1) in each assessment (T0-T48) in both groups are shown in Table 7. In the comparison between the groups, there was no statistical difference. In groups 1 (control) and 2 (OVH), over the evaluated times, there was difference only in T4 (4 hours after sedation or surgery) in relation to the other times, with higher means in T4. In group $2(\mathrm{OVH})$, the mean T4 blood glucose values $(\mathrm{mg} / \mathrm{dL})$ were above the reference values for canines, constituting a hyperglycemic state.

Table 4 - Medians and standard deviations of the simple descriptive scale (SDS) for sedation scores at different times during the assessment in group 1 (control) and group $2(\mathrm{OVH})$. Veterinary Hospital of the Federal University of Minas Gerais, June to October 2015

\begin{tabular}{lcccccccc}
\hline & N & T0 & T4 & T8 & T12 & T24 & T36 & T48 \\
\hline Group 1 (Control) & 8 & 1 & $2 \pm 0.35$ & $1 \pm 0.46$ & 1 & 1 & 1 & 1 \\
Group 2 (OVH) & 7 & $\mathrm{~A} \mathrm{a}$ & $\mathrm{B} \mathrm{a}$ & $\mathrm{A} \mathrm{a}$ & $\mathrm{A} \mathrm{a}$ & $\mathrm{A} \mathrm{a}$ & $\mathrm{A} \mathrm{a}$ & $\mathrm{A} \mathrm{a}$ \\
& & 1 & $2 \pm 0.38$ & $2 \pm 0.53$ & 1 & 1 & 1 & 1 \\
& & $\mathrm{~A} \mathrm{a}$ & $\mathrm{B} \mathrm{a}$ & $\mathrm{AB} \mathrm{a}$ & $\mathrm{A} \mathrm{a}$ & $\mathrm{A} \mathrm{a}$ & $\mathrm{A} \mathrm{a}$ & $\mathrm{A} \mathrm{a}$ \\
\hline
\end{tabular}

$\mathrm{N}=$ number of animals. Values followed by different capital letters are significantly different $(\mathrm{p}<0.05)$ among assessment times, and different lower case letters indicate that the values differ significantly between groups, according to the Kruskal-Wallis test.

Table 5 - Medians and standard deviations of the modified Glasgow pain scale (MGPS) scores at different times during the assessment in group 1 (control) and group $2(\mathrm{OVH})$. Veterinary Hospital of the Federal University of Minas Gerais, June to October 2015

\begin{tabular}{|c|c|c|c|c|c|c|c|c|}
\hline & $\mathbf{N}$ & TO & T4 & T8 & T12 & T24 & T36 & T48 \\
\hline Group 1 & 8 & $5.4 \pm 2.3 \mathrm{DE} a$ & $3.9 \pm 0.9 \mathrm{DE} a$ & $2.9 \pm 1.8 \mathrm{BCDE} a$ & $3.6 \pm 1.4 \mathrm{CDE} a$ & $2.1 \pm 1.7 \mathrm{BCD}$ a & 2.2 $21.5 \mathrm{BCDE}$ a & $1.8 \pm 2.2 \mathrm{BCD} a$ \\
\hline Group 2 & 7 & $3.2 \pm 1.8 \mathrm{BCDE}$ a & $5.2 \pm 1.0 \mathrm{Ea}$ & $1.8 \pm 2.2 \mathrm{BCD}$ a & $1.5 \pm 1.9 \mathrm{ABC} a$ & $0.1 \pm 2.0 \mathrm{AB} a$ & $0.9 \pm 0.5 \mathrm{Ab}$ & $0.1 \pm 0.3 \mathrm{Ab}$ \\
\hline
\end{tabular}

$\mathrm{N}=$ number of animals. Values followed by different capital letters are significantly different $(\mathrm{p}<0.05)$ among assessment times, and different lower case letters indicate that the values differ significantly between groups, according to the Kruskal-Wallis test.

Table 6 - Means and standard deviations of serum cortisol levels ( $\mu \mathrm{g} / \mathrm{dL}$ ) at different assessment times in group 1 (control) and group 2 (OVH). Veterinary Hospital of the Federal University of Minas Gerais, June to October 2015

\begin{tabular}{lllllllll}
\hline & $\mathbf{N}$ & T0 & T4 & T8 & T12 & T24 & T36 & T48 \\
\hline Group 1 (Control) & $\mathbf{8}$ & $9 \pm 4 \mathrm{~A} \mathrm{a}$ & $5 \pm 2 \mathrm{~A} \mathrm{a}$ & $6 \pm 3 \mathrm{~A} \mathrm{a}$ & $7 \pm 3 \mathrm{~A} \mathrm{a}$ & $8 \pm 2 \mathrm{~A} \mathrm{a}$ & $7 \pm 3 \mathrm{~A} \mathrm{a}$ & $8 \pm 7 \mathrm{~A} \mathrm{a}$ \\
Group 2 (OVH) & $\mathbf{7}$ & $5 \pm 3 \mathrm{~A} \mathrm{a}$ & $7 \pm 3 \mathrm{~A} \mathrm{a}$ & $5 \pm 2 \mathrm{~A} \mathrm{a}$ & $3 \pm 1 \mathrm{~A} \mathrm{a}$ & $4 \pm 1 \mathrm{~A} \mathrm{a}$ & $4 \pm 2 \mathrm{Aa}$ & $4 \pm 2 \mathrm{~A} \mathrm{a}$ \\
\hline
\end{tabular}

$\mathrm{N}=$ number of animals. Values followed by different capital letters are significantly different $(\mathrm{p}<0.05)$ between assessment times, and different lower case letters indicate significant differences between groups, according to the SNK test. Reference serum cortisol values for canines: 1.80-4.00 $\mu$ g/dL. Source: Jericó (2015).

Table 7 - Means and standard deviations of serum glucose $(\mathrm{mg} / \mathrm{dL})$ at different assessment times in group 1 (control) and group 2 (OVH). Veterinary Hospital of the Federal University of Minas Gerais, June to October 2015

\begin{tabular}{lcccccccc}
\hline & N & T0 & T4 & T8 & T12 & T24 & T36 & T48 \\
\hline Group 1 (Control) & $\mathbf{8}$ & $91 \pm 5$ & $100 \pm 9.2$ & $92 \pm 5$ & $88 \pm 10$ & $97 \pm 7$ & $97 \pm 7$ & $94 \pm 7$ \\
& & $\mathrm{Ba}$ & $\mathrm{Aa}$ & $\mathrm{B} \mathrm{a}$ & $\mathrm{B} \mathrm{a}$ & $\mathrm{B} \mathrm{a}$ & $\mathrm{B} \mathrm{a}$ & $\mathrm{B} \mathrm{a}$ \\
Group 2 (OVH) & $\mathbf{7}$ & $96 \pm 5$ & $118 \pm 11$ & $109 \pm 12$ & $101 \pm 11$ & $102 \pm 14$ & $102 \pm 8$ & $100 \pm 8$ \\
& & $\mathrm{~B} \mathrm{a}$ & $\mathrm{A} \mathrm{a}$ & $\mathrm{B} \mathrm{a}$ & $\mathrm{B} \mathrm{a}$ & $\mathrm{B} \mathrm{a}$ & $\mathrm{B} \mathrm{a}$ & $\mathrm{B} \mathrm{a}$ \\
\hline
\end{tabular}

$\mathrm{N}=$ number of animals. Values followed by different capital letters are significantly different $(\mathrm{p}<0.05)$ between assessment times, and different lower case letters indicate significant differences between groups, according to the SNK test. Reference values of glucose for canines: 70-110 mg/dL. Source: Nelson et al. (2004). 


\section{Discussion}

The results regarding the VAS and SDS pain scales are compatible with the expected results, and all animals in group 1 (not operated) presented zero pain score at all times evaluated. In Group $2(\mathrm{OVH})$, the highest averages (3.8 in VAS and 3 in SDS) were observed in the immediate post-operative period (T4), probably because of the surgical nociceptive stimulus that causes central sensitization and the inflammatory reaction (Alves et al., 2017; Fox et al., 1998; Srithunyarat et al., 2016). At T4, analgesic rescue was performed with tramadol hydrochloride on animals that presented SDS scores $>2$. The average and individual values declined at subsequent times ( $\mathrm{T} 8$ to $\mathrm{T} 48$ ), indicating a decrease in central sensitization and the inflammatory reaction, as well as a lower influence on the neuroendocrine and metabolic responses (Alves et al., 2017; Fox et al., 1998; Srithunyarat et al., 2016).

Selmi et al. (2009) compared different analgesic protocols in dogs after OVH using the VAS. The results were similar in all protocols, and there was a strong correlation between the VAS and University of Melbourne pain scales. The present study found similar pain results between the VAS and SDS in the animals assessed.

Holton et al. (1998) discussed the trend in the use of the VAS, SDS, and numerical scale separately and found a significant variability among observers at all scales evaluated. They reported the relevance of using the three scales together as a way of minimizing the influence of each scale separately on pain assessment. Matičić et al. (2010) also used the VAS to assess pain in animals and considered it a valid, reliable, and sensitive method for assessing pain in animals. Reid \& Nolan (1991) used the VAS and SDS pain and sedation scales, and they deemed the VAS more satisfactory and sensitive. In the present study, three pain scales (VAS, SDS, and MGPS) were applied together with the same purpose of increase the reliability of the analyses.

The results concerning the VAS and SDS scales of sedation were also compatible with what was expected. Group 1 (control) displayed a sedative effect at T4 (4h after methadone administration), since this drug is an opioid agonist with a sedative effect (Górniak, 2006; Lamont \& Mathews, 2007). In Group 2 (OVH), as expected, a residual and longer sedative effect was found at $\mathrm{T} 4$ and $\mathrm{T} 8$, probably because of the drugs used in anesthesia and analgesic postoperative protocol in Group 2 (Branson, 2007).

Both stress and pain can lead to changes in animal behavior, such as body posture, level of activity, and changes in locomotion frequency (Lefman \& Prittie, 2019; Malm et al., 2005a; Väisänen et al., 2005). Among the VAS, SDS and
MGPS scales applied in this study, the MGPS was the only one that considered behavioral parameters to assess pain.

The rescue anesthesia is necessary when the MGPS score is higher than 3.5 (Campagnol, 2011; Murrell et al., 2008). In the present study, in a general descriptive analysis, the means found in some time points were above this value. Surprisingly, in group 1 (control), the MGPS means were above 3.5 at T0 (before sedation), T4, and T12. Although the MGPS is a pain scale, some criteria and parameters applied are directly related to stress. Thus, while group 1 dogs were free of pain, because they did not undergo surgery, their MGPS means may have been above 3.5 due to stress.

In Group 2 (OVH), the MGPS means were above 3.5 only at T4. These highest means found at T4 may have been linked to the stress associated with the painful stimulus of surgical intervention, although it must be highlighted that the MGPS estimates parameters directly related to pain (Campagnol, 2011; Murrell et al., 2008).

Despite the painful stimulus in group $2(\mathrm{OVH})$, there were lower percentages of animals with a MGPS scores above 3.5 at almost all times in this group, indicating that stress has a remarkable influence on the MGPS. At T36 and T48 (Table 5), lower means were found in the group that had undergone surgery (group 2), possibly because of the sedative effect of CNS depression by tramadol used in the analgesic protocol of this group (Górniak, 2006).

Kim et al. (2012) used the MGPS to evaluate different anesthetic protocols. In their results, all dogs had a zero score in the pre-operative evaluation. The animals were from shelters, just as in the present study, but they underwent a five-day adaptation period in the veterinary hospital before the beginning the assessments. Therefore, we suspect that the high MGPS scores at T0 (pre-surgery) occurred in the present study were related to the $24 \mathrm{~h}$ period of hospital adaptation that was possibly short and thus the animals were still under the effect of stress when starting this study. Stress was probably related to hospitalization, changes in environment, the presence of strange persons, the unpredictability of events and stimuli that occurs when animals are brought to a clinical practice (Srithunyarat et al., 2016).

In the present study, three pain assessment scales were used and the results obtained demonstrated that MGPS was significantly influenced by the stress experienced by animals. This was evidenced by the fact that, at several assessments time points, animals not subjected to a painful stimulus displayed values equal or greater than those of dogs that had undergone surgery. It is important to highlight that signs of stress in dogs can be subjective, 
variable and can also be manifestations of pain. Examples include excessive activity, avoidance and hiding from caretakers, low body posture and vocalization (Lefman \& Prittie, 2019). This could explain, in the present study, the results of MGPS evaluation, that includes some of these behavioral observations. Furthermore, rescued dogs tend to increase the activity of the hypothalamic-pituitary-adrenal axis, the body's primary stress-responsive neuroendocrine system (Willen et al. 2017).

At T0 (before sedation/surgery), none of the animals were under any medication, and they had not experienced any painful stimulus. Therefore, the presence of high serum cortisol levels ( $\mu \mathrm{g} / \mathrm{dL}$ ) at T0 suggests that they were displaying a response to stress that was not linked to any nociceptive stimulus (Freeman et al., 2010; Hekman et al., 2012; Hellyer et al., 2007; Michelsen et al., 2012; Zanella et al., 2009). Malm et al. (2005b) and Horta et al. (2015) assessed pain and stress in dogs subjected to OVH and mastectomy, respectively, and found no evidence of increased serum cortisol levels $(\mu \mathrm{g} / \mathrm{dL})$ before surgery, unlike the results presented in this study.

The fact that the female dogs in the present study came from shelters and were rescued from streets probably explains the tendency of higher cortisol $(\mu \mathrm{g} / \mathrm{dL})$ when compared to other studies, highlighting that in the work of Malm et al. (2005a, 2005b) the bitches were submitted to a hospital adaptation for 15 days, and in the study by Horta et al. (2015), the bitches were domiciled and came from a hospital routine. Similar results were described in Srithunyarat et al. (2016) study, when higher levels of cortisol $(\mu \mathrm{g} / \mathrm{dL})$ seen before surgery could possibly be due to the white coat effect when the dogs were less accustomed to the hospital environment.

Hennessy et al. (1997) conducted a study involving animals from shelters. They found that the animals had serum cortisol levels $(\mu \mathrm{g} / \mathrm{dL})$ significantly higher than those of domiciled animals, suggesting that staying in a shelter causes prolonged activation of the hypothalamicpituitary-adrenal axis. This fact can be explained by the unpredictable nature of the events in these environments, and the consequent loss of control of the animal over the events around them, triggering stress in animals (Shiverdecker et al., 2013; Willen et al., 2017).

Furthermore, the decrease of cortisol levels $(\mu \mathrm{g} / \mathrm{dL})$ in group $2(\mathrm{OVH})$ from T12 (12 h after surgery) may be justified by the administration of tramadol for analgesia throughout the hospitalization period for this group. Opioids tend to have a sedative effect due to CNS depression, reducing anxiety and pain (Gorniak, 2006; Lamont \& Mathews, 2007).
In the present study, the operated animals (group 2) were submitted to multimodal analgesic protocol with tramadol (Cloridrato de Tramadol, União Química Farmacêutica Nacional S/A, Jabaquara, São Paulo, Brasil), dipyrone and scopolamine (Buscofin ${ }^{\circledR}$, União Química Farmacêutica Nacional S/A, Jabaquara, São Paulo, Brazil)). Even with mild pain evidenced in some moments, there was no significant difference in cortisol ( $\mu \mathrm{g} / \mathrm{dL}$ ) between G1 and G2. Thus, it is suggested that hospitalization and its inherent factors, such as manipulation, strangers to the animals, confinement, fear and anxiety may be more relevant in stress response than pain or surgical procedure. Matičić et al. (2010) conducted a study comparing different surgical techniques in dogs and also concluded that plasma cortisol levels $(\mu \mathrm{g} / \mathrm{dL})$ depend heavily on the patient's condition and environmental circumstances.

Although both groups showed increased glycemia (mg/ $\mathrm{dL}$ ) in T4, the presence of hyperglycemic state observed only in the average of group $2(\mathrm{OVH})$ was possibly due to nociceptive stimulation, intensifying the stress signals in these animals. Increased serum cortisol levels $(\mu \mathrm{g} / \mathrm{dL})$ are also known to lead to increased gluconeogenesis which, associated with increased circulating catecholamines, promotes insulin resistance, culminating in hyperglycemia (Hellyer et al., 2007; Horta et al., 2015; Zanella et al., 2009).

In the present study, increased mean serum cortisol levels $(\mu \mathrm{g} / \mathrm{dL})$ were found in group 1 (control) at all assessment times. In group $2(\mathrm{OVH})$, they were found at T0 (pre-surgery), T4, and T8. However, hyperglycemia state was only found in the mean values of T4 in group 2 , suggesting that hyperglycemia has a closer link with pain than with stress in these animals.

Among the animals evaluated in this study $(n=15)$, there was no significant correlation between cortisol $(\mu \mathrm{g} / \mathrm{dL})$ and glucose $(\mathrm{mg} / \mathrm{dL}$ ) levels (a negative correlation of 0.07 was obtained using the Pearson correlation test). Equally, Matičić et al. (2010) reported no statistical difference in glucose levels (mg/dL) in dogs submitted to different surgical techniques to correct a ruptured cranial cruciate ligament. Glycemia (mg/dL) was not correlated with other parameters evaluated and was not considered a good indicator of pain or stress. Horta (2013) observed hyperglycemic status in dogs submitted to partial and radical mastectomy, with higher means in radical mastectomy. He attributed the presence of hyperglycemic state to nociceptive stimulus, intense for both techniques and superior in radical mastectomy. In the current study, a hyperglycemic state was only found at $\mathrm{T} 4$ in group $2(\mathrm{OVH})$, suggesting that it was linked with post-operative pain. 


\section{Conclusions}

The VAS and SDS scales were effective and reliable for pain assessment. Stress was a component that interfered with the results obtained through MGPS. Cortisol ( $\mu \mathrm{g}$ / $\mathrm{dL}$ ) was a good indicator of stress in the animals of this study, being more influenced by the stress of hospitalization than the painful stimulus related to surgery, considering the analgesic protocol used. Glycemia $(\mathrm{mg} / \mathrm{dL})$ was a good indicator of pain and a little sensitive indicator regarding stress in the evaluated animals. Stress was similar in both groups (control and $\mathrm{OVH}$ ), indicating that the hospitalization of the animals was more relevant in establishing stress than the surgical procedure $(\mathrm{OVH})$ and associated pain.

\section{References}

Alves JEO, Silveira MD, Vieira EMP, Vidal LWM. Mecanismos fisiopatológicos da nocicepção e bases da analgesia perioperatória em pequenos animais. Acta Biomed Bras. 2017;8(1):56-68. http://dx.doi.org/10.18571/acbm.122.

Beerda B, Schilder BH, Van Hooff JARAM, de Vries HW. Vanhooff, JARAM, Vries, HW. Manifestations of chronic and acute stress in dogs. Appl Anim Behav Sci. 1997;52(3-4):307-19. http://dx.doi.org/10.1016/S01681591(96)01131-8.

Branson KR. Injectable and alternative anesthetic techniques. In: Tranquilli WJ, Thurmon JC, Grimm KA, editors. Lumb \& Jones' veterinary anesthesia and analgesia. 4th ed. Iowa: Blackwell Publishing; 2007. p. 273-300.

Broom DM. Animal welfare: concepts and measurement. J Anim Sci. 1991;69(10):4167-75. http://dx.doi. org/10.2527/1991.69104167x. PMid:1778832.

Campagnol D. Farmacologia clínica da metadona peridural e intravenosa em cães [tese]. Botucatu: Faculdade de Medicina, Universidade Estadual de São Paulo; 2011.

Fossum TW. Cirurgia de pequenos animais. 3a ed. Rio de Janeiro: Elsevier; 2008.

Fox SM, Mellor DJ, Lawoko CRO, Hodge H, Firth EC. Changes in plasma cortisol concentrations in bitches in response to different combinations of halothane and butorphanol, with or without ovariohysterectomy. Res Vet Sci. 1998;65(2):125-33. http://dx.doi.org/10.1016/S00345288(98)90163-1. PMid:9839890.

\section{Conflict of Interest}

Authors declare no conflicts of interest or competing interests associated with this research.

\section{Ethics Statement}

This study was approved by the Ethics Committee on the Use of Animals of the Federal University of Minas Gerais (UFMG) on March 30, 2015, under protocol 66/2015.

\section{Acknowledgements}

This study was funded by the Research Support Foundation of the State of Minas Gerais (Fapemig) (Belo Horizonte, Brazil), and the National Council for Scientific and Technological Development (CNPq) (Brasília, Brazil).

Freeman LJ, Rahmani EY, Al-Haddad M, Sherman S, Chiorean MV, Selzer DJ, Snyder PW, Constable PD. Comparison of pain and postoperative stress in dogs undergoing natural orifice transluminal endoscopic surgery, laparoscopic, and open oophorectomy. Gastrointest Endosc. 2010;72(2):373-80. http://dx.doi.org/10.1016/j.gie.2010.01.066. PMid:20537637.

Górniak SL. Hipnoanalgésicos e neuroleptoanalgesia. In: Spinosa HS, Górniak SL, Berbardi MM, editors. Farmacologia aplicada à medicina veterinária. 4a ed. Rio de Janeiro: Guanabara Koogan; 2006. p. 176-184.

Hekman JP, Karas AZ, Dreschel NA. Salivary cortisol concentrations and behavior in a population of healthy dogs hospitalized for elective procedures. Appl Anim Behav Sci. 2012;141(3-4):149-57. http://dx.doi.org/10.1016/j. applanim.2012.08.007. PMid:24204086.

Hekman JP, Karas AZ, Sharp CR. Psychogenic stress in hospitalized dogs: cross species comparisons, implications for health care, and the challenges of evaluation. Anim. 2014;4(2):331-47. http://dx.doi.org/10.3390/ani4020331. PMid:25126422.

Hellyer PW, Gaynor JS. Acute postsurgical pain in dogs and cats. Compend Contin Educ Pract Vet. 1998;20(2):140-53.

Hellyer PW, Robertson SA, Fails AD. Pain and its management. In: Tranquilli WJ, Thurmon JC, Grimm KA, editors. Lumb \& Jones' veterinary anesthesia and analgesia. 4th ed. Iowa: Blackwell Publishing; 2007. p. 31-57.

Hennessy MB, Davis HN, Williams MT, Mellott C, Douglas CW. Plasma cortisol levels of dogs at a public animal shelter. 
Physiol Behav. 1997;62(3):485-90. http://dx.doi.org/10.1016/ S0031-9384(97)80328-9. PMid:9272654.

Holton LL, Scott EM, Nolan AM, Reid J, Welsh E. Relationship between physiological factors and clinical pain in dogs scored using a numerical rating scale. J Small Anim Pract. 1998;39(10):469-74.http://dx.doi.org/10.1111/j.1748-5827.1998. tb03681.x. PMid:9816569.

Horta RS, Figueiredo MS, Lavalle GE, Costa MP, Cunha RMC, Araújo RB. Surgical stress and postoperative complications related to regional and radical mastectomy in dogs. Acta Vet Scand. 2015;57(1):34. http://dx.doi.org/10.1186/s13028015-0121-3. PMid:26104069.

Horta RS. Avaliação da nocicepção, complicações pósoperatórias e impacto na qualidade de vida provocados por duas técnicas cirúrgicas de mastectomia na espécie canina [dissertação]. Belo Horizonte: Escola de Veterinária, Universidade Federal de Minas Gerais; 2013.

Jericó MM. Tratado de medicina interna de cães e gatos. 1a ed. São Paulo: Roca; 2015. (vol. 2).

Kim YK, Lee SS, Suh EH, Lee L, Lee HC, Lee HJ, Yeon SC. Sprayed intraperitoneal bupivacaine reduces early postoperative pain behavior and biochemical stress response after laparoscopic ovaryhisterectomy in dogs. Vet J. 2012;191(2):188-92. http://dx.doi.org/10.1016/j. tvjl.2011.02.013. PMid:21397535.

Kitchen N, Arason AL, Bittle JL. Panel report of the colloquium on recognition and alleviation of animal pain and distress. J Am Vet Med Assoc. 1987;191(10):1186-91. PMid:3692950.

Koknaroglu H, Akunal T. Animal welfare: an animal science approach. Meat Sci. 2013;95(4):821-7. http://dx.doi. org/10.1016/j.meatsci.2013.04.030. PMid:23664009.

Lamont LA, Mathews KA. Opioids, Nonsteroidal Antiinflammatories, and Analgesic Adjuvants. In: Tranquilli WJ, Thurmon JC, Grimm KA, editors. Lumb \& Jones' veterinary anesthesia and analgesia. 4th ed. Iowa: Blackwell Publishing; 2007. p. 241-271.

Lefman SH, Prittie JE. Psychogenic stress in hospitalized veterinary patients: causation, implications, and therapies. J Vet Emerg Crit Care. 2019;29(2):107. http://dx.doi. org/10.1111/vec.12821. PMid:30861632.
Lloyd J. minimising stress for patients in the veterinary hospital: why it is important and what can be done about It. Vet Sci. 2017;4(2):2-22. http://dx.doi.org/10.3390/ vetsci4020022. PMid:29056681.

Malm C, Savassi-Rocha PR, Gheller VA, Oliveira HP, Lamounier AR, Foltynek V. Ovário-histerectomia: estudo experimental comparativo entre as abordagens laparoscópica e aberta na espécie canina. II - Evolução clínica pós operatória. Arq Bras Med Vet Zootec. 2005a;57(2, Suppl 2):162-72. http:// dx.doi.org/10.1590/S0102-09352005000800006.

Malm C, Savassi-Rocha PR, Gheller VA, Oliveira HP, Lamounier AR, Foltynek V. Ovário-histerectomia: estudo experimental comparativo entre as abordagens laparoscópica e aberta na espécie canina. III - Estresse pela análise do cortisol plasmático. Bras Med Vet Zootec. 2005b;57(2):58490. http://dx.doi.org/10.1590/S0102-09352005000500003.

Matičić D, Stejskal M, Pećin M, Kreszinger M, Pirkić D, Vnuk D, Smolec O, Rumenjak V. Correlation of pain assessment parameters in dogs with cranial cruciate surgery. Vet Arh. 2010;80(5):597-609.

Michelsen J, Heller J, Wills F, Noble GK. Effect of surgeon experience on postoperative plasma cortisol and $\mathrm{C}$ reative protein concentrations after ovariohysterectomy in the dog: a randomized trial. Aust Vet J. 2012;90(12):474-8. http://dx.doi. org/10.1111/j.1751-0813.2012.01013.x. PMid:23186096.

Moll X, Fresno L, García F, Prandi D, Andaluz A. Comparison of subcutaneous and transdermal administration of buprenorphine for pré-emptive analgesia in dogs undergoing elective ovariohysterectomy. Vet J. 2011;187(1):124-8. http:// dx.doi.org/10.1016/j.tvjl.2009.11.011. PMid:20056555.

Morton CM, Reid J, Scott EM, Holton LL, Nolan AM. Application of a scaling model to establish and validate an interval level pain scale for assessment of acute pain in dogs. Am J Vet Res. 2005;66(12):2154-66. http://dx.doi. org/10.2460/ajvr.2005.66.2154. PMid:16379662.

Möstl E, Palme R. Hormones as indicators of stress. Domest Anim Endocrinol. 2002;23(1-2):67-74. http://dx.doi. org/10.1016/S0739-7240(02)00146-7. PMid:12142227.

Murrell JC, Psatha EP, Scott EM, Reid J, Hellebrekers LJ. Application of a modified form of the Glasgow pain scale in a veterinary teaching centre in the Netherlands. Vet Rec. 2008;162(13):403-8. http://dx.doi.org/10.1136/vr.162.13.403. PMid:18375984. 
Nelson RW, Turnwald GH, Willard MD. Endocrine, metabolic and lipid disorders. In: Willard MD, Tvedten $\mathrm{H}$, editors. Small animal clinical diagnosis by laboratory methods. 4th ed. Philadelphia: W.B. Saunders; 2004. p. 165-207. http:// dx.doi.org/10.1016/B0-72-168903-5/50013-6.

Reid J, Nolan AM. A comparison of the postoperative analgesic and sedative effects of flunixin and pap aver etum in the dog. J Small Anim Pract. 1991;32(12):603-8. http://dx.doi. org/10.1111/j.1748-5827.1991.tb00900.x.

Selmi AL, Lins BT, Cesar FB, Figueiredo JP, Duque JC. A comparison of the analgesic efficacy of vedaprofeno, carprofen or ketofen after ovariohysterectomy in bitches. Cienc Rural. 2009;39(3):785-90. http://dx.doi.org/10.1590/ S0103-84782008005000104.

Shiverdecker MD, Schiml PA, Hennessy MB. Human interaction moderates plasma cortisol and behavioral responses of dogs to shelter housing. Physiol Behav. 2013;109:75-9. http:// dx.doi.org/10.1016/j.physbeh.2012.12.002. PMid:23234768.

Srithunyarat T, Höglund OV, Hagman R, Olsson U, Stridsberg M, Lagerstedt AS, Pettersson A. Catestatin, vasostatin, cortisol, temperature, heart rate, respiratory rate, scores of the short form of the Glasgow composite measure pain scale and visual analog scale for stress and pain behavior in dogs before and after ovariohysterectomy. BMC Res Notes. 2016;9(1):381. http://dx.doi.org/10.1186/s13104016-2193-1. PMid:27484122.
Stone EA. Sistema reprodutivo. In: Slatter D, editor. Manual de cirurgia de pequenos animais. 3a ed. São Paulo: Manole; 2007. p. 1487-1502.

Väisänen MA-M, Valros AE, Hakaoja E, Raekallio MR, Vainio OM. Pre-operative stress in dogs: a preliminary investigation of behavior and heart rate variability in healthy hospitalized dogs. Vet Anaesth Analg. 2005;32(3):15867. http://dx.doi.org/10.1111/j.1467-2995.2005.00188.x. PMid:15877662.

Willen RM, Mutwill A, MacDonald LJ, Schiml PA, Hennessy MB. Factors determining the effects of human interaction on the cortisol levels of shelter dogs. Appl Anim Behav Sci. 2017;186:41-8. http://dx.doi.org/10.1016/j. applanim.2016.11.002.

Zanella R, Thomazi G, Guizzo N Jr, Spagnolo JD, Guimarães LD, Brun MV. Cortisol plasmático como indicador de estresse em colopexias laparoscópicas com implante de tela de polipropileno em cães. Acta Sci Vet. 2009;37(3):231-7. http://dx.doi.org/10.22456/1679-9216.16335.

Financial Support: This study was funded by the Research Support Foundation of the State of Minas Gerais (Fapemig) (Belo Horizonte, Brazil), and the National Council for Scientific and Technological Development (CNPq) (Brasília, Brazil). 